\title{
Logical Normativity and Rational Agency-Reassessing Locke's Relation to Logic
}

\author{
H U A P I N G L U - A D L E R*
}

\begin{abstract}
A substantive body of literature has been dedicated to explaining Locke's crucial role in the development of a new logic in the seventeenth and eighteenth centuries, commonly referred to as the "logic of ideas" or "facultative logic." I examine Locke's relation to logic from a different angle. I focus on two philosophical issues that permeate his remarks about logic in various texts. One is about what grounds the alleged authority of putative logical rules. The other concerns the relation between logic and the psychology of reasoning. These issues are not only historically significant but also continuous with an ongoing modern discourse in philosophy of logic.
\end{abstract}

KEY WORDS agency, Locke, logic, normativity, syllogism

\section{I . I N T R O D U C T I O N}

There is an exegetical quandary when it comes to interpreting Locke's relation to logic.

On the one hand, over the last few decades a substantive amount of literature has been dedicated to explaining Locke's crucial role in the development of a new logic in the seventeenth and eighteenth centuries. John Yolton names this new logic the "logic of ideas," while James Buickerood calls it "facultative logic." Either way, Locke's Essay is supposedly its "most outspoken specimen" or "culmination." Call this reading the 'New Logic interpretation.'

On the other hand, from the typical standpoint of a philosopher accustomed to the modern (Boolean-Fregean) conception of logic, whatever Locke-indeed, whatever most of the seventeenth- and eighteenth-century philosophers—had to

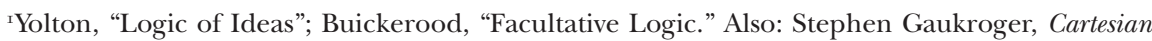
Logic; Peter Schouls, Reasoned Freedom, 22-25; Frederick Michael, "Epistemology"; Paul Schuurman, Ideas; and Hannah Dawson, Locke, 2I-22. For the most recent discussion of relevant primary and secondary literature, see Marco Sgarbi, Kant and Aristotle, I9-77.

${ }^{2}$ Schuurman, Ideas, 2; and Sgarbi, British Empiricism, 229.

*Huaping Lu-Adler is Assistant Professor of Philosophy at Georgetown University Journal of the History of Philosophy, vol. 56, no. I (2018) 75-99 
say about logic seems to be of little interest. Many historians and non-historians alike share this impression. James Franklin, for instance, makes the following dismissive comments about the "voluminous works of 'logic'" produced in the eighteenth century:

they are full of what would now be called cognitive psychology, epistemology, semiotics, philosophy of logic, and introspection. They are full also of invective, against "scholastic headpieces," full indeed of everything except logic, in the modern sense of formal logic. (Franklin, "Artifice," 838)

Notably, The Cambridge History of Eighteenth-Century Philosophy, in which Franklin's article appears, has no separate category for logic. The topics that correspond to what Paul Schuurman (in his Ideas) identifies as the three components of the logic of ideas-ideas, human faculties, and method-are treated in the section "The Science of Human Nature." Franklin's article appears under the heading "Natural Philosophy" and sets aside a scant four pages to discuss logic (after twenty pages on mathematics). This arrangement reflects the view that eighteenth-century writings on the so-called "logic" did not contain "much that has commanded respect since."

The same view is implicit in the newest edition of The Oxford Dictionary of Philosophy. The entry on logic defines it as the "general science of inference," the aim of which is "to make explicit the rules by which inferences may be drawn, rather than to study the actual reasoning processes that people use, which may or may not conform to those rules." The history of logic is then divided into exactly two traditions. One is "Aristotelian logic or traditional logic" (equated with syllogistic logic), which has allegedly "dominated the subject until the I9th century." The other is "modern logic" or "mathematical logic," with Boole and Frege as its founding figures. As for Locke, his "great distinction" lies in an entirely different place: He paid "close attention to the actual phenomena of mental life." 4 Piece together these remarks, and you get the sense that Locke's most valuable philosophical work must have nothing to do with logic. A survey of the 6o-plus entries related to logic in the Stanford Encyclopedia of Philosophy will leave you with the same impression. In short, few working philosophers today suspect there is anything noteworthy about Locke's relation to logic. ${ }^{5}$

It would be unhelpful to attribute this phenomenon either to a lack of historical knowledge or to the modern bias about what counts as logic. Beneath it is a genuine sense of puzzlement about methodology. This puzzlement finds its expression in George $\quad$ H. R. Parkinson's review of Wilhelm Risse's Die Logik der Neuzeit II, which covers developments in logic between I640 and I780. Risse's volume discusses not only familiar figures in the history of formal logic, such as Leibniz and Hobbes, but also those who had rarely been associated with logic in any positive way, including Descartes, Locke, and Spinoza, among others. Parkinson grants that early modern conceptions of logic, as Risse treats them, are much broader than formal logic, being "permeated with questions of epistemology, metaphysics and

${ }^{3}$ Franklin, "Artifice," 838.

${ }^{4}$ Simon Blackburn, Dictionary, 278-79.

5One exception is Leo Groarke's "Informal Logic," which briefly mentions Locke as one among many representatives (including Aristotle) of a tradition of fallacy theory that is now part of informal logic. 
psychology." Yet, Parkinson demurs, "there seems to be a case for operating with a more stringent, and modern, conception of what is to count as logic," which would somewhat "simplify the issues to be dealt with-issues which are, in any case, complex enough."

Parkinson has thereby posed a methodological challenge to the New Logic interpretation: What will we lose by sorting apart issues of epistemology, psychology etc. in the seventeenth- and eighteenth-century philosophy and treating them separately (without thereby denying that, at bottom, they may be intimately connected)? By distinguishing logic in the strict modern sense from other disciplines, one may add, we can better appreciate the various areas of philosophical developments in that period for what they really are. Otherwise, what do we gain by insisting on mixing sundry non-logical subjects and subsuming them under "logic"?

Buickerood, for one, is sensitive to this kind of challenge. He reminds us that, in Locke's work, we are confronted with an entirely different kind of logic, one that carries out the "theoretical task of identifying, discriminating and analyzing the cognitive faculties and their operations." As such, it is "deeply at odds with previous and succeeding conceptions of logic." In particular, much of it would today be classified as "epistemology" and "psychology." Hence, we should approach Locke's work on logic with an open mind, refraining from judging it "by alien criteria of intelligibility and satisfactoriness." Unfortunately, this total isolation of Locke's work from the modern way of thinking about logic, as thoughtful as it is, may serve only to deepen the gulf between the New Logic interpretation and the prevalent view that, wherever Locke's philosophical greatness may lie, it definitely has nothing to do with logic.

In this paper, I examine Locke's relation to logic from a different angle. The goal is to highlight certain aspects of the relation that tend to be obscured or downplayed by the New Logic interpretation and that can be meaningfully incorporated into the ongoing philosophical discourse on logic. ${ }^{8}$ To this end, it is important to distinguish logic and philosophy of logic. ${ }^{9}$ Buickerood alludes to this when he mentions the distinction "between the study of the cognitive faculties and the discipline of logic itself," but decides to make little of this distinction in his analysis of Locke's work and its influence on the eighteenth-century logic, for "many eighteenth-century philosophers themselves tended to ignore any distinction possible between these inquiries." Accordingly, when attributing "facultative logic" to Locke, Buickerood means this designation to encompass both logic and the study of its foundation and sees no need to give distinct treatment to the latter. ${ }^{\text {10 }}$ We shall see, however, that Locke himself was evidently aware of the distinction, and that two of his most celebrated critics in the eighteenth century, Leibniz and Kant, would engage his views on logic primarily at the foundational level.

'Parkinson, "Review of Risse," 300.

${ }^{7}$ Buickerood, "Facultative Logic," I63.

${ }^{8} \mathrm{My}$ interpretive project here does not contradict the New Logic interpretation as such. The two projects emphasize different aspects of Locke's relation to logic. This difference in emphasis may reflect deeper disagreements over methodological issues, though, e.g. whether we should treat Locke's relation to logic as a purely historical issue confined to a particular era, or whether we should try to analyze it in terms of philosophical issues that are still salient today.

${ }^{9}$ On this distinction, see Susan Haack, Philosophy of Logics, I-2.

${ }^{10}$ Buickerood, "Facultative Logic," I 62-63. 
Here is my plan. I begin with a preliminary analysis of the texts where Locke talks about logic, drawing special attention to his comments on the purpose, limits, and grounds of logic and on how individuals, qua rational agents, ought to approach any purported logical system (section 2). In these terms, I reconstruct Locke's critique of syllogism (as the established paradigm of formal logic) in the Essay (section 3.I). I then zero in on two specific issues raised by the critique, both of which pertain to logical normativity. One is about what grounds the alleged authority of putative logical rules (section 3.2). The other involves the relation between logic and thought, which Locke rightly urges us to clarify in order to explain the real possibility for logical rules to be norms of thought (section $3 \cdot 3$ ). In section 4, I conclude by indicating ways to explore further implications of my analysis, especially when it comes to appreciating Locke's unique influence on some of the most significant developments in the eighteenth-century philosophy of logic.

My immediate concern is to break from the exegetical quandary described above so as to counter an all-too-common tendency to overlook Locke's philosophical contributions to logic. It is with this concern in mind that I will submit an alternative way to read some of his texts by highlighting certain philosophical issues about logic that are still salient today. Accordingly, the textual analysis in section 2 and the reconstruction of Locke's critique of syllogism or formal logic in section 3 will serve to foreground his insights regarding two issues that are central to current debates on logical normativity: namely, the relationship between the psychology of reasoning and the normativity of logic and the relationship between (free) rational agency and the command of purported logical norms. Meanwhile, the texts under consideration will inevitably raise questions about, say, how to assess Locke's actual position in the history of logic (in relation to previous as well as subsequent developments) and how to understand the nature and subject matter of the very discipline of logic in light of his works. These are important but highly complex issues that require separate treatments. I shall only indicate, when appropriate, particular points about them that merit further investigation.

\section{L O C K E O N L O G I C - A P R E L I M I N A R Y \\ T E X T UA L A N A L Y S IS}

In the final section of the Essay, Locke gives a tripartite division of sciences: physics or natural philosophy, practical philosophy, and semiotics or the doctrine of signs (ideas and words). ${ }^{\text {II }} \mathrm{He}$ adds that, insofar as words are "the most usual" kind of

\footnotetext{
${ }^{11}$ This division, coupled with Locke's subsequent reference to semiotics as a kind of logic, raises interesting questions that had been debated since antiquity. Diogenes mentions two Hellenistic tripartite divisions of philosophy in his Lives (VII.39-42; X.30-3I), namely, the Stoic division into logic (to logikon), physics, and ethics, versus the Epicurean one into canonic (to kanonikon), physics, and ethics. While explaining sources of these divisions, Diogenes reports profound disagreements over the subject matter of logic/canonic and its relation to physics and ethics, e.g. whether it has priority over these two branches and if so in what sense. Similar questions dominated scholastic discussions on the nature and subject matter of logic and its relation to other philosophical disciplines: Is logic an autonomous scientia, or an organon to all sciences, or both? If logic is indeed a scientia, what is its proper domain of investigation and on what principles (principia) is it grounded? (Jacopo Zabarella's immensely influential De Natura Logicae illustrates the weight of these questions.) It can be instructive to examine Locke's tripartite division in reference to these questions.
} 
signs, semiotics "is aptly enough termed also logikê, Logick." "² A likely historical reference here is the scholastic terminist logic, which studied properties of meaningful words or terms (sermones).$^{\mathrm{I} 3}$ Whether this is what Locke has in mind does not concern us here. ${ }^{\mathrm{I}}$ What I find telling, especially when we consider his other remarks about logic, is that he does not straightforwardly identify the third science as 'logic.'

Although the Essay as a whole revolves around words and ideas, Locke does not claim to have thereby worked out a new logic. Having stressed the importance of investigating signs "as the great instruments of knowledge," he says:

perhaps, if they [i.e. ideas and words] were distinctly weighed, and duly considered, they would afford us another sort of Logick and Critick, than what we have been hitherto acquainted with. (Essay, IV.xxi.4, 72I)

Locke leaves it open as to what the anticipated logic might be, for example, as to whether it simply is a theory of signs, or something built on such a theory. Earlier in the Essay, citing Hooker's claim that discovering "the right helps of true Art and Learning" would make enormous "difference in Maturity of Judgment between Men therewith inured, and that which now Men are," Locke says:

I do not pretend to have found, or discovered here any of those right helps of Art, this great Man of deep Thought mentions. . . It is sufficient for me, if . . I I shall have given Occasion to others, to cast about for new Discoveries, and to seek in their own Thoughts, for those right Helps of Art, which will scarce be found, I fear, by those who servilely confine themselves to the Rules and Dictates of others. (Essay, IV.xvii.7, 680)

Again, Locke does not elaborate on the right helps of art that logic is billed to supply. He only notes that they will be "something out of the way" and "wholly new, and unborrowed," as far as he is concerned. ${ }^{\text {Is }}$ At any rate, the important point to note here is that he follows Hooker in connecting the prospect of discovering such helps with the ability to judge maturely, namely, to judge for oneself and independently of the dictates of others. We will encounter this connection several more times.

Now let us see how Locke personally responded to the suggestion of treating the Essay as a work of logic or turning it into one. The natural place to begin is William Molyneux's following claim:

Logick has put on a Countenance clearly different from what it appeared in formerly ... to none do we owe for a greater Advancement in this part of philosophy, than to the incomparable Mr. Locke, who, in his Essay concerning Human Understanding, has rectified more received Mistakes, and delivered more profound Truths, established

${ }^{12}$ Essay, Book IV, Chapter xxi, Section 4, 720.

${ }^{13}$ This reference raises two interesting questions. First, how shall we position Locke's semiotics, as a theory of linguistic and mental signs, vis-à-vis the scholastic terminist logic? Second, what are we to make of the fact that, for both Locke and the terminist logicians (especially William Ockham and John Buridan), the study of signs/terms is to have far-reaching consequences for how to approach metaphysical issues (e.g. whether there are universals, natural kinds etc.) and so is inevitably tied with the realism-nominalism controversy? See E. Jennifer Ashworth, "Words"; Walter Ott, Language, Dawson, Locke, and L. M. De Rijk, "Semantics and Ontology."

${ }^{14}$ For a brief analysis of Locke's identification of semiotics with logic, which is absent from his writings before the first edition of the Essay, see Buickerood, "Facultative Logic," I74-75.

${ }^{15}$ Essay, IV.xvii.7, 680. 
on Experience and Observation, for the Direction of Man's mind in the Prosecution of Knowledge, (which I think may be properly term'd Logick) than are to be met with in all the Volumes of the Antients. (Molyneux, Dioptrica Nova, dedicatory letter) ${ }^{\mathrm{I}}$

Locke thanked Molyneux for this "extraordinary complement," without confirming the status of the Essay as a work of logic. ${ }^{17}$ Molyneux brought up the subject again in a letter to Locke in December, I962:

your next [edition of the Essay] should be of a Model wholy New, and that is by Way of Logick, something accommodated to the Usual Forms, together with the Considerations of Extension, Solidity, ... etc. and of the Mind of Man, and its Powers, as may make up a Compleat Body of what the Schooles call Logicks and Metaphysicks.

(\# I 579, Correspondence, iv, 60I)

Locke politely declined to follow this advice. His explanation conveyed a degree of pessimism about which, if any, logic to teach in the schools. On the one hand, if the students must study logic at all, "it should be nothing but proposition and syllogisme." On the other hand, these things "may be spared too," as long as they are directed at cultivating skills in disputation, which is "but an ill (not to say the worst) way to knowledge."18 Molyneux claimed to be "fully convinced" by this argument, but still wished to get the Essay "promoted the easier in our Universitys."

It would take John Wynne to affect the promotion Molyneux had in mind. In January I 695, Wynne wrote to Locke with the proposal of publishing an abridgment of the Essay. To make his case, Wynne complained about the prevalent "Vulgar Systems" being "useles and insignificant" and serving "to perplex and confound, instead of enlightning and improving our Reasons." The Essay represented the exact opposite, Wynne argued, and so should be brought "into vogue and credit, and thereby into common and general use." ${ }^{\circ}$ In response, Locke was "very glad" that the Essay could be made useful for the young minds in pursuit of knowledge, and expressed flexibility about how to design the abridgment for that purpose. ${ }^{2 \mathrm{I}}$

Beyond this initial approval, though, Locke seemed indifferent to the projected abridgment. Wynne wrote three follow-up letters about it. In the first, he predicted that the resulting product would "far exceed, and be of much more real use, then what commonly we learn and teach, under the Name of Logick."22 The second letter informed Locke that the finished Abridgment had been mailed to him along

\footnotetext{
${ }^{16}$ Molyneux's notion of logic as that which provides rules for directing human mind in the pursuit of knowledge differs from the notion of it as a science of signs/terms that Locke alluded to at the end of the Essay. But Locke also gestured toward the former notion in his remarks about the "right helps of art," which fit with the then standard conception of logic as organon. In principle, these two notions are not mutually exclusive: Many scholastic philosophers, answering the question of whether logic is a scientia or an organon (see n. I I above), held that it is a science that can serve as or provide instrumental support to other sciences. It is unclear where Locke stands on the matter.

${ }^{17}$ Locke to Molyneux, I 6 July I692, \# I 5 I 5, Correspondence, iv, 479. Reference to Locke's letters are to their dates and archival numbers, followed by the relevant volume and pagination of Locke's Correspondence.

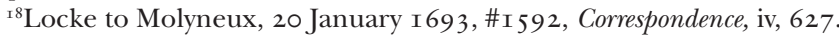

${ }^{19}$ Molyneux to Locke, 2 March I 693, \# I609, Correspondence, iv, 649.

${ }^{2 \circ}$ Wynne to Locke, 3 I January I695, \# I 843, Correspondence, v, 26 I-62.

${ }^{21}$ Locke to Wynne, 8 February I 695, \# I 846, Correspondence, v, 266-67.

${ }^{22}$ Wynne to Locke, 30 March I695, \# I 869, Correspondence, v, 3 I 9.
} 
with the Dedication. ${ }^{23}$ The third letter confirmed that the book was committed to printing. ${ }^{24}$ Locke never answered any of these letters. When he did mention Wynne's work to Molyneux, he cared more about the latter being pleased with its design: "possibly that which you once proposed may be attained [through the Abridgment] too, and I was pleased with the gentleman's design for your sake." ${ }^{25}$ Molyneux turned out to be utterly disappointed after reading the Abridgment. He wished it would be "undone," and faulted his former self for wanting to see the Essay "put into the Form of a Logick for the Schooles." ${ }^{26}$ It does not follow, of course, that Molyneux had thereby retracted his view of the Essay as a genuine work of logic. It remained to be the case, however, that Locke himself never explicitly endorsed such a view. ${ }^{27}$

Meanwhile, Locke started working on some additions to the fourth edition of the Essay, including a chapter titled "Of the Conduct of the Understanding" (intended as the final chapter, but never completed) ${ }^{28}$ Some see the Conduct as a work of logic on its own right. Kenneth Winkler argues that it in fact "has a stronger claim [than the Essay] on the status of 'logic' in the usual sense," since this is where Locke develops a "positive logic." ${ }^{29}$ When we inspect Locke's remarks about logic in the Conduct, however, it is far from clear that he intends to offer a positive logic in the usual sense (whatever this means).

The Conduct begins with the proposition that the faculty of understanding is "The last resort a man has recourse to in the conduct of himself" and so it is "of the highest concernment that great care should be taken of the understanding to conduct it right in the search of knowledg and in the judgments it makes." Locke laments that the "Logick now in use," which has been regarded as "the only art taught in the Schools for the direction of the minde in the study of the Arts and sciences," is "not sufficient to guide the understanding." ${ }^{\circ}$ He then cites Bacon's remarks about logic in the preface to the Instauratio Magna: "who[ever] attributed soe much to Logick perceived very well and truly that it was not safe to trust the understanding to it self without the guard of any rules." As for the remedy offered

${ }^{23}$ Wynne to Locke, 20 April I 695, \# I 884, Correspondence, v, 346-47. Wynne addresses the Dedication to Locke, declaring that the Abridgment "alone will . . . afford such helps for the improvement of reason as are, perhaps, in vain sought after in those books which profess to teach the art of reasoning" (Wynne, Abridgment, vii).

${ }^{24}$ Wynne to Locke, 5 June I 695, \#I9 I 5 , Correspondence, v, 392.

${ }^{25}$ Locke to Molyneux, 26 April I695, \#I 887, Correspondence, v, 352. Also: Locke to Molyneux, 2 July I695, \#I92 I, Correspondence, v, 406. To give this sentiment some context, Locke said to Molyneux in the second letter: "My decaying health does not promise me any long stay in this world, you are the only person in it, that I desire to see once, and to converse some time with, before I leave it." (Correspondence, v, 407-8)

${ }^{26}$ Molyneux to Locke, 6 June I696, \#2 I00, Correspondence, v, 653.

${ }^{27}$ This raises the question of whether for the New Logic interpretation it suffices that the Essay was received as a work of alternative logic-likely it was so received in some circles, given the popularity of Wynne's Abridgment - regardless of whether Locke intended it as such. I wish to leave this question open, but also add that Wynne's (New Logic) reading does not represent the only way in which the Essay was received. In Kant and many other important eighteenth-century German thinkers, for instance, we shall see a rather different reception by way of philosophy of logic.

${ }^{28}$ Locke to Molyneux, Io April I697, \#2243, Correspondence, vi, 87.

${ }^{29}$ Winkler, "Lockean Logic," I 57. Cf. Schuurman, "General Introduction," 90-96.

${ }^{3 \circ}$ Conduct, I-2. All references to Conduct are by paragraph numbers. 
by the conventional logic, it "reachd not the evil but became a part of it." In particular, it not only "comes very far short of the subtilty in the reall performances of nature," but has also "served to confirme and establish errors rather than to open a way to truth." Hence, "it is absolutely necessary that a better and perfecter use and imployment of the minde and understanding should be introduced." ${ }^{1}$

According to Thomas Fowler, this appeal to Bacon suggests that Locke designed the Conduct "to supplement and enlarge the logic of the schools by the addition of practical precepts and warnings, which should be instrumental in leading to the discovery of truth rather than in helping to secure victory in disputation." ${ }^{2}$ The text is certainly open to this interpretation. But what would it mean to "supplement" the old logic? One way to do so is to fill the gaps left by the old logic, so that the new and old logics can be two complementary systems that serve in different domains of human life. This characterizes Bacon's plan "to expound the doctrine of improving and perfecting the use of reason in the investigation of things, and of the true helps of the intellect." The doctrine in question counts as "a kind of logic," Bacon explains, which agrees with "common logic" in seeking to "make ready and supply helps and assistance to the intellect" but differs from the latter "in its end, order of demonstration, and the inquiry's starting points." 33 Developing this new logic is the task of Part II of Bacon's Instauratio magna, namely Novum Organum or True Directions concerning the Interpretation of Nature. ${ }^{34}$ Inductive method constitutes the core of this logic, which is directly opposed to syllogistic demonstration when it comes to investigating nature: If the latter "lets nature slip through its fingers," induction is precisely "that form of demonstration which ... bears down on nature." 35

Locke gives no indication in the Conduct that he intends to supplement common logic in this Baconian way. He has portrayed himself in the Essay as an "UnderLabourer"-not "Master-Builder"-in the commonwealth of learning, whose task consists "in clearing Ground a little, and removing some of the Rubbish, that lies in the way to Knowledge." ${ }_{36}$ This self-image does not seem to have changed in the Conduct. If anything, reading the Novum Organum should give him a further reason to focus more on foundational matters than on working out a new system. ${ }^{37}$ After all, one is now confronted with the Aristotelian syllogistic and the

${ }^{31}$ Conduct, 3. The translation is Locke's. For comparison, see Bacon, Instauratio, I 8-2 I.

${ }^{32}$ Fowler, "Introduction," xxiii-xxiv.

${ }^{33}$ Francis Bacon, Instauratio, 29. Bacon clarifies that his intention is not to reject syllogism but to restrict its "jurisdiction" to "popular arts and matters of opinion," as it is "totally ineffective in the active department of the sciences" (Bacon, Instauratio, 30 ).

${ }^{34}$ Bacon, Instauratio, 27-29.

${ }^{35}$ Bacon, Instauratio, 3 I.

${ }^{36}$ Essay, Epistle, 9-IO. I am using the notion of under-laborer in the generic sense of "one who prepares the ground for something substantive." In the Essay, this notion also has a specific meaning that involves logic qua semiotics. It concerns Locke's tripartite division of all that falls within the compass of human understanding. He includes semiotics as the third branch in this division because words and ideas are the "ways and means, whereby the Knowledge of both [physics and ethics], are attained and communicated" (Essay, IV.xxi.I, 720). Presumably, a correct theory of words and ideas is not yet knowledge properly so called, but only prepares us for the attainment thereof by clarifying, among other things, the nature and rightful use of words. Insofar as the Essay revolves around this project of semiotics, it is a work of under-laborer.

${ }^{37}$ Locke likely read Novum Organum after completing the Essay and before starting the Conduct (Schuurman, "General Introduction," 3 I). 
Baconian inductive logic submitting competing offers of "true helps" to human understanding in pursuit of knowledge.$^{8}$ It would be uncharacteristically dogmatic of Locke to claim allegiance to one side over the other without first reflecting on the grounds for a fair adjudication. In fact, rather than embroiling himself in the competition, Locke will be working out a framework within which each rational individual can decide for herself whether a claim of authenticity is legitimate, be it from the Baconian or the Aristotelian side.

To get some perspective here, let us pause to consider Locke's remarks about logic in his famous controversy with Edward Stillingfleet, which took place during the same period when he was writing the Conduct. Locke addresses Stillingfleet's criticisms of the Essay in several letters written between January I697 and May I698. In the second letter (June I697), he characterizes one of Stillingfleet's charges as that of "novelty," viz. of advancing "new way of reasoning; . . new way of ideas; new method of certainty." In response, Locke clarifies what is new in the Essay and what is not. Apropos his "way by ideas," for example, which Stillingfleet has contrasted with the Aristotelian "way by reason," Locke says: "if it be new, it is but a new history of an old thing." What is "old" is that humans have "always performed the actions of thinking, reasoning, believing, and knowing, just after the same manner that they do now." Meanwhile, Locke claims, "nobody . . . had, in their writings, particularly set down wherein the act of knowing precisely consisted." 39 Thus,

if I have done any thing new, it has been to describe to others more particularly than had been done before, what it is their minds do, when they perform that action which they call knowing: and if, upon examination, they observe I have given a true account of that action of their minds in all the parts of it; I suppose it will be in vain to dispute against what they find and feel in themselves. And if I have not told them right, and exactly what they find and feel in themselves, when their minds perform the act of knowing, what I have said will be all in vain. (Locke, Works, vol. 3, I43-44)

Locke thus invokes "the experience of mankind" as the only authoritative basis for judging whether a theory of reasoning is true. The judgment is left to each individual. The problem, however, is that our minds can be so full of unexamined biases that we may not be ready to pass mature judgments on what is proposed to us. If Locke was already concerned about this situation when he first mentioned in the Essay the need to remove "rubbish," it should worry him even more now that he has seen how people can find faults with every bit of his Essay simply "for its antiquity or novelty." ${ }^{40}$ When we resume our reading of the Conduct, we shall notice that biases of antiquity or novelty are among the rubbish to be removed.

${ }^{38}$ Although Bacon interpreted his inductive method and the established deductive method as complementary and presiding over separate domains of human affairs, this was not how a typical Aristotelian schoolman saw the matter. As Locke's critique of syllogism will indicate, the deductive method was still considered—as it had been since Thomas Aquinas's Commentary on Aristotle's theory of demonstrative science-the proper one for any science (in the strict sense of scientia). It is in this sense that the inductive and deductive logics make "competing" offers of true helps to the human understanding in its quest for knowledge.

${ }^{39}$ Locke, Works, vol. 3, I34-35, I37, I43.

${ }^{4 \circ}$ Locke, Works, vol. 3, I 38 , I 43 . 
Against this backdrop, there is indeed a sense in which the Conduct "supplements" the extant logic, be it the Baconian inductive logic or the Aristotelian syllogisticnot by adding yet another logic, however, but by clearing the grounds for each individual to make reasoned judgments about whether those logics do offer the right "helps" to her understanding. It is no wonder, then, that in the Conduct Locke never directly either endorses or rejects any purported logic per se. Rather, he pays more attention to the conditions of rational agency, which one must exercise in order to have an enlightened relation to any purported logic..$^{4 \mathrm{I}}$

Accordingly, the better part of the Conduct consists in cataloguing, diagnosing, and prescribing remedies for various kinds of prejudices or partialities, which can weaken and hinder our ability to obtain knowledge. There is a notable ethical dimension to this project. As Fowler summarizes it, Locke's analysis concerns "the moral causes of fallacious reasoning: prejudice, haste, mental indolence, overregard for authority, love of antiquity or novelty, self-sufficiency, despondency, and the various other conditions of mind which are quite as effective in barring the way to truth." ${ }^{42}$ The purpose of the analysis is to facilitate the intellectual freedom that is essential to our rational agency. Locke writes:

in the examination of our principles and not receiveing any for such nor building on them till we are fully convinced as rational creatures of their solidity truth and certainty, consists that freedom of the understanding which is necessary to a rational creature and without which it is not truly an Understanding. (Conduct, 36; also, 37)

Take a close look at Locke's explicit remarks about logic in the Conduct, and you will see that they all to some degree manifest this concern about intellectual freedom. He says, for instance, that a "man of reason" differs from a "logical chicanner," not because they use different logical tools, but because they relate to the same logic in different ways. An enlightened individual takes logic for what it is-a severely limited tool-and "exercise[s] the freedom of his reason and understanding in such a [comprehensive] latitude" that "his mind will be strengthened, his capacity inlarged his facultys improved ... to the full extent of its capacity." 43 By contrast,

men designed for scholars have often their heads soe fild and warmed with disputes on logical questions that they take those airy useless notions for real and substantial knowledg, and think their understanding soe well furnishd with science that they need not looke any farther into the nature of things, or descend to the mechanical drudgery of experiment and enquiry. (Conduct, 84)

In these terms, Locke is not advocating that we banish the conventional logic altogether, but rather warning against a misguided and slavish attitude toward it. He can make his case from "prudence": given how "narrow" and "slow" our mind is in learning new truths, we had better not dwell on trifling matters and get distracted thereby from our main target, namely "real and substantial" knowledge. This applies not only to logic but also to other disciplines: single-minded preoccupation

\footnotetext{
${ }^{4 \mathrm{I}} \mathrm{My}$ operative notion of agency in this paper echoes the account of moral agency in Antonia LoLordo's Moral Man, according to which liberty (freedom), personality, and rationality are the necessary and sufficient conditions of agency. I focus on the first condition, with the notion of selfdetermination at its core (see n. 74 below).

${ }^{42}$ Fowler, "Introduction," xxiii.

${ }^{43}$ Conduct, 99.
} 
with any one of them-be it mathematics, chemistry, theology, or anything of the sort—can close one's mind and make one's judgment prejudicial. ${ }^{44}$

When Locke makes claims about syllogism specifically, his point is again not to reject it tout court, but to stress its limitedness. As he puts it elsewhere,

I grant the method of syllogism is right as far as it reaches; its proper business is to show the force and coherence of any argumentation, and to that it would have served very well, and one might certainly have depended on the conclusions as necessarily following from the premises in a rightly ordered syllogism, if the applauded art of disputing had not been taken for knowledge, ... and so the end lost for which they were invented. (Locke, Life, 223, emphasis added)

The italicized parts of this passage accentuate the pith of Locke's take on syllogism: One must return and confine it to its intended place. It is by certain schoolmen's abuse, he claims, that "the rules left us by the ancients for the conducting our thoughts in the search, or at least the examination of truth have been defeated." 45 The alleged abuse consists in using the syllogistic method as sufficient means for knowledge, an end that was not part of its original design.

In the same vein, in Some Thoughts on Education, Locke cautions against "captious logical disputes": They encourage "fallacy, wrangling, and opiniatry" and "spoil the judgment, and put a man out of the way of right and fair reasoning." One can discover truths, he reminds his reader, only "by a mature and due consideration of things themselves, and not by artificial terms and ways of arguing." Hence, if young students must study logic, rhetoric, and grammar (these subjects constitute the trivium of the then standard university curriculum), they must do so "in the shortest systems [that] could be found, without dwelling long on the contemplation and study of those formalities." Not that there is anything intrinsically wrong with logical or other kinds of formalities. Rather, as long as the study is oriented toward skillful disputation as opposed to "civil conversation," Locke worries that it can turn the youngster into "an insignificant wrangler, opiniatre in and priding himself in contradicting others." 46

This concludes my preliminary textual analysis. It does not rule out that one may still construct some kind of new logic from the relevant texts, or that, as a matter of historical fact, these texts contributed to the development of one. To deny these interpretative options is to risk descending into a merely verbal debate over the meaning of 'logic.' More importantly, I espouse exegetical pluralism when it comes to assessing Locke's relation to logic. If the New Logic interpretation shall remain a viable framework for this assessment, it is not the only one-and certainly not one that is convincing to the skeptics who, as I presented their standpoint in the introduction, saw little philosophical gain in treating as logic an array of topics that we may understand more clearly under separate headings such as epistemology, philosophy of language, philosophy of logic etc.

For the purpose of this paper, the above textual analysis uncovered reasons to think that Locke might have found it more pressing to address the most basic

${ }^{44}$ Conduct, 3 I, 48-49, 84 .

${ }_{45}$ Locke, Life, 222.

${ }^{46}$ Locke, Works, vol.8, 9I, I 77-78. For an excellent study of the educational environment in which Locke made such complaints, see W. Henry Kenney, Oxford Training, I-44. 
philosophical problems raised by previous developments in logic than to work out a new system of logic. To recap, given that it is the task of logic to offer right helps to human understanding and that we face at least two competing logics in this regard, the Baconian inductive logic and the Aristotelian syllogistic, Locke leaves it to each individual to judge which, if either, logic provides the helps that suit her best. Such judgments are inevitably fallible, but it is more important that one arrive at them on one's own terms. Whatever judgment one settles on, it must be from a reflective and free exercise of one's rational agency. One of Locke's self-appointed tasks is to clear the ground for such mature judgments. He does so mainly by (i) constructing a natural history of the mind, i.e. a "historical, plain" account of our cognitive faculties, ${ }^{47}$ and (ii) articulating the precepts for attaining the intellectual freedom essential to our pursuit of knowledge. Broadly speaking, the Essay and the Conduct fulfill (i) and (ii) respectively. The concern with intellectual freedom also permeates the Essay, though, which appeals to a reader who is "not content to live lazily on scraps of begg'd Opinions" but "sets his own Thoughts on work." ${ }^{48}$ Bearing this last point in mind, let us take a close look at Locke's critique of syllogism in the Essay.

\section{LOCKE ON SYLLOGISM IN THE ESSAY}

Locke gives his most extensive treatment of syllogism in the chapter of the Essay titled "Of Reason," where he engages the view that "syllogism, as is generally thought, be the proper instrument of it [reason], and the usefullest way of exercising this faculty." ${ }^{49}$ On a typical reading, Locke thereby rejects the Aristotelian syllogistic, a rejection that is neither original nor persuasive. As Jonathan Barnes puts it, both Bacon and Descartes had made similar objections to syllogism, and even these philosophers "were only reheating the cabbage," since the Aristotelian logic, with syllogism at its core, had plenty of critics in the past. Regarding Locke's argument in particular, Barnes thinks the only worthwhile exegetical task is to clarify, among other things, which logic is the intended target and what is proposed in its place. On Barnes's reading, Locke equates the Aristotelian syllogistic with formal logic and so "in rejecting the syllogism he is rejecting formal logic" to replace it with a new way of reasoning. Barnes finds the purported new way of reasoning inadequate, no matter how charitably one tries to parse it. He concludes: As great a philosopher as Locke was otherwise, he "had little understanding of logic." 50 In similar terms, Fowler finds it easy to give "defence of [formal] logical rules against the attacks of Locke." ${ }^{\text {I }}$

I shall argue, however, that Locke's critical analysis of syllogism in the Essay has a significantly different focus and raises much more sophisticated philosophical challenges than Barnes's reading suggests. In brief, the analysis primarily concerns the alleged authority of formal logic — syllogism being its paradigm example-and

\footnotetext{
${ }^{47}$ Essay, I.i.2, 44. On the Essay as a natural history of the mind, see Peter Walmsley, Rhetoric, 32-58.

${ }^{48}$ Essay, Epistle, 6.

${ }^{49}$ Essay, IV.xvii.4, 670.

${ }^{50}$ Barnes, "Syllogism," I $06-7$, I I I, I 24-32.

${ }^{51}$ Fowler, "Notes," I09.
} 
with the related issue of rational agency. Locke's target, to be precise, is the view that syllogism is "the only proper instrument of reason and means of knowledge" and therefore a universal and necessary condition of what makes one "rational." ${ }_{52}$ The point of his contention is not that syllogism can provide no useful assistance to reason whatsoever, but that it does not deserve the title as the universal standard for the correct use of reason.

In what follows, I present Locke's analysis in a way that highlights these points (section 3.I). After clarifying the nature of the analysis as a "critique" of syllogism, I explain how Leibniz, in his New Essays, engages it as such and thereby helps to reveal some of the deep philosophical issues involved in their disagreement over syllogism in particular and formal logic in general (section 3.2). I then briefly discuss one topic that Leibniz glosses over, namely, the relation between logic (as an abstract formal theory) and actual reasoning (as a conscious mental process that involves agency) (section 3.3).

\section{I.ILLocke's Argument}

The chapter "Of reason" begins with the account of reason as "a Faculty . . . whereby Man is supposed to be distinguished from Beasts." This faculty serves "for the enlargement of our Knowledge, and regulating our Assent." It encompasses two capacities: sagacity, whereby it "finds out"; illation or inference, whereby it "so orders the immediate Ideas, as to discover what connexion there is in each link of the Chain, whereby the Extremes are held together." ${ }_{53}$

The language of agency is conspicuous in Locke's description of these capacities. He talks about the mental acts of perceiving, discerning, and judging, which must involve "choice" and "direction" as opposed to being "effects of Chance and Hazard." 54 The contrast between directed and random acts suggests that an agent, insofar as she is rational, must subject these acts to rules. Presumably, such rules cannot determine one's mental acts in a mechanistic fashion. Nor can they be imposed on the strength of external authority, convention, or anything of the sort. Rather, an agent must recognize any purported rules of reasoning as authoritative norms on her own terms and regulate her reasoning activities accordingly. In that connection, Locke's basic task in "Of reason" is to examine, firstly, whether syllogism can be legitimately prescribed as the necessary instrument for the proper use of reason in general and, secondly, how we as rational agents should relate to syllogism in cases where it can facilitate our reasoning activities to some extent.

Locke builds his arguments partly on the following observations and assumptions. First, syllogism is an artificial device invented by Aristotle. One acquires the ability to use it by being taught in the schools. Second, many people reason well without being acquainted with syllogism. Third, among those who have studied logic and can construct syllogisms, most regard various syllogistic forms as valid "by an implicit Faith in their Teachers" without understanding why they are valid. ${ }^{55}$ In these terms, Locke gives a reductio ad absurdum to the following effect:

\footnotetext{
${ }^{52}$ Essay, IV.xvii.4, 67 I, emphasis added.

${ }^{53}$ Essay, IV.xvii.I-2, 668-69.

${ }^{54}$ Essay, IV.xvii.2, 669.

${ }^{55}$ Essay, IV.xvii.4, 670-7I.
} 
(i) Suppose: syllogism is the necessary condition of rationality.

(ii) It implies that "before Aristotle there was not one Man that did or could know any thing by Reason; and that since the invention of Syllogisms, there is not one of Ten Thousand that doth."

(iii) This implication is both false (given the above observations) and absurd, for "God has not been so sparing to Men to make them barely two-legged Creatures, and left it to Aristotle to make them Rational, i.e. those few of them that he could get so to examine the Grounds of Syllogisms."

Therefore, the supposition is false..$^{56}$

The sentence quoted in (iii), despite its rhetorical appearance, contains two serious points. First, if in certain cases syllogism does assist one's reasoning, what makes one rational in such cases is not the mere use of syllogism, but one's doing so from a clear understanding of why or "upon what ground" certain forms of syllogistic inferences are cogent. ${ }^{57}$ Second, if this reasoned application of syllogism is sufficient for rationality, it is not necessary. Locke's appeal to God is significant in this regard, as it directs our attention to the native capacity of human intellect.

[God] has given [humans] a Mind that can reason without being instructed in Methods of Syllogizing: The Understanding is not taught to reason by these Rules; it has a native Faculty to perceive the Coherence, or Incoherence of its Ideas, and can range them right, without any such perplexing Repetitions. (Essay, IV.xvii.4, 67I)

On this assumption of the native capacity of our mind, Locke then explains what it means to make a correct inference and how syllogism may (or may not) fit into the picture.

On his account, drawing a "right" inference amounts to "finding out the intermediate Ideas, and taking a view of the connexion of them, placed in a due order." For example, one can infer from "men shall be punished in another world" to "men can determine themselves" only by finding out all the intermediate ideas and arranging them in this order: men shall be punished; god the punisher; just punishment; the punished guilty; could have done otherwise; freedom; self-determination. By these ideas "thus visibly link'd together in train, i.e. each intermediate Idea agreeing on each side with those two it is immediately placed between, the Ideas of Men and self-determination appear to be connected." Only when I clearly perceive in my own mind this train of ideas, should I be convinced of the "reasonableness" of the inference..$^{8}$

Though granting that such an inference "may be reduced to [Aristotle's] Forms of Syllogism," Locke contends that the certainty one attains of its cogency does not depend on any such reduction, but on "the visible agreement of Ideas." After all, it is not "Syllogism that discovered those Ideas, or shewed the connexion of them, for they must be found out, and the perceived, before they can rationally be made use of in Syllogism." In short, the "natural order" in which the given ideas are perceived as connected must precede and "direct"

${ }^{56}$ Essay, IV.xvii.4, 67 I.

${ }^{57}$ Essay, IV.xvii.4, 67I

${ }^{5}$ Essay, IV.xvii.4, 672-73. Locke's choice of the example, which represents self-determination as an essential property of humans, seems deliberate: the reasoning by which one arrives at this representation is itself an instance of self-determination (see $n .74$ below). 
one's syllogistic arrangement of them. The latter adds nothing to the inference in terms of its perceived "force." When an inference is syllogistically formulated, neither those skilled with syllogisms nor those who are not will appreciate its cogency any better. The former "see the eonnection of each intermediate Idea with those it stands between ... as well before as after the Syllogism is made." The latter, being ignorant of syllogisms, "cannot know whether they are made in right and conclusive Modes and Figures or no, and so are not at all helped by the Forms they are put into." 59

Without rejecting syllogism as such, Locke's final point is that each individual must judge for herself whether she needs its assistance in order to reason properly:

if Men skill'd in, and used to Syllogisms, find them assisting to their Reason in the discovery of Truth, I think they ought to make use of them. All that I aim at is, that they should not ascribe more to those Forms than belongs to them; And think that Men have no use, or not so full a use of their reasoning Faculty without them. (Essay, IV.xvii.4, 678)

Locke illustrates this point by comparing the perceptive faculty of the mind to eyes. Just as some eyes require spectacles to see clearly, a mind may have gotten so accustomed to syllogisms that the use of them has "so dimmed its Sight, that it cannot without them see consequences or inconsequences in Argumentation." It does not follow, however, that no one can perceive clearly without such devices. To claim otherwise is to esteem "Art ... a little too much to depress and discredit Nature." In fact, reason "by its own Penetration where it is strong, and exercised, usually sees, quicker and clearer without Syllogism." Ultimately, though, each individual "knows what best fits his own Sight."

This push against prescribing syllogism for the general use of reason is applicable to any purported formal logical tools. It is not, as Barnes suggested, that Locke knows so little about logic as to conflate the Aristotelian syllogistic with all of formal logic. Rather, Locke urges his reader to see any putative formal-logical theory as what it is, namely an artificial tool that some individuals may find useful in certain cases but should not be universally prescribed on that account. One may disagree with Locke's conception of formal logic as just a contrived artificial tool, but it takes more philosophical ingenuity than logical cleverness to challenge him on this point. Here is where Leibniz will enter the scene.

\section{I.玉. Locke's Argument as a "Critique"}

Locke's argument about syllogism in the Essay is more a 'critique'-in a Kantian sense of the term (see below) - than a 'criticism' as some take it to be ${ }^{61}$ It is intended not so much to reveal what is wrong with syllogism itself, as to remind us of its limitations and demote it from the throne of knowledge that it has occupied for too long without entitlement. Locke bases his account of the lawful place of syllogism on an examination of the native capacity of human intellect. This explains why Kant singles him out to represent the "critical" as opposed to "dogmatic" method of philosophizing and regards the Essay as the "ground" of true logic.

\footnotetext{
${ }^{59}$ Essay, IV.xvii.4, 67 I-74.

${ }^{60}$ Essay, IV.xvii.4, 678.

${ }^{6} \mathrm{E}$. J. Lowe, Routledge Guidebook, I 82.
} 
All the efforts of our philosophy are

I. dogmatic

2. critical.

Among critical philosophers Locke deserves priority. . .

Locke's book de intellectu humano is the ground of all true logica. (BL 24:37) ${ }^{62}$

The critical method that Kant ascribes to Locke "consists in investigating the procedure of reason itself, in analyzing the whole human faculty of cognition." ${ }^{3}$ In these terms, the Lockean insight is that all legitimate claims of logic must build on an analysis of human intellect.

Whether Locke is right to base such an analysis on empirical observations is a further question, which will turn out to be an exceedingly complex one. What is important to note here is that, to defend syllogism or any formal-logical theory without begging the question against Locke, one had better meet him at the level of foundational questions of the sort just mentioned. This level is where Leibniz's defense of syllogism takes off, a brief review of which will signal how far down the ladder of difficult philosophical issues a controversy over syllogism can drive us.

Leibniz begins by separating two conceptions of syllogism. One represents "the scholastic manner of arguing," which Leibniz agrees is "not much employed in the world" and, when taken all too seriously, can only cause "prolixity and confusion." Syllogism in the strict sense, however, belongs to "the universal forms of general logic," through which we demonstrate particular kinds of formal arguments as valid. The mastery of syllogism in this sense, Leibniz argues, is vital to good reasoning. After all, the mind cannot always easily see whether one thing follows from another. Especially when assessing other people's arguments, one may be "over-impressed . . . by enthymemes which wrongly assume that the propositions they suppress are evident, and even by faulty inferences," so that one can be unsure about their validity "until a demonstration is given" according to formal-logical rules. Hence, it is "necessary ... [to] have a strict logic, though of a different type from the scholastic one." To the extent that syllogism is an integral part of this strict logic, its "invention" is "one of the finest, and indeed one of the most important, to have been made by the human mind." ${ }^{4}$

Although syllogism as a formal device was invented (by Aristotle), Leibniz argues, "laws of logic . . . are nothing but the laws of good sense, set into order in writing." In other words, syllogism stands for certain objective laws of human reason that have always been at play, although Aristotle was the first to present them in a distinct manner, expressing them schematically, and arranging them systematically. This claim about syllogism is compatible with Locke's observation that "the common run of men know nothing about logic as an art [logique artificielle] and that they nevertheless reason as well as-and sometimes better than-people who are practiced in logic." For even those commoners' good reasoning depends on an implicit use of the relevant logical rules. ${ }^{65}$ It is just that, as Leibniz puts it

\footnotetext{
${ }^{62}$ References to Kant's works other than the Critique are to the volume and pagination of his Gesammelte Schriften.

${ }^{63} L \mathrm{~L}$ 9: 32.

${ }^{64} \mathrm{NE}$ Book IV, Chapter xvii, Section 4, 478-82.

${ }^{65} \mathrm{NE}$ IV.xvii.4, 480, 482.
} 
while talking about principles of identity and contradiction, we often use logical laws "without having them explicitly in mind." ${ }_{66}$

For general principles enter into our thoughts, serving as their inner core and as their mortar. Even if we give no thought to them, they are necessary for thought, as muscles and tendons are for walking. The mind relies on these principles constantly; but it does not find it so easy to sort them out and to command a distinct view of each of them separately. ... And it is in that way that many things are possessed without the possessor's knowing it. (NE I.i.20, 84)

This argument invokes a distinction between explicit and implicit knowledge that Locke would find problematic. ${ }^{67}$ It also presupposes a model of mind that is directly opposed to Locke's tabula rasa. It does not follow, however, that Leibniz has thereby begged the question against Locke. Rather, both seek a theory of mind that can explain our ability to reason well. By Leibniz's analysis, this ability is unintelligible on the Lockean model. To use his favorite metaphor of marble and statue, "if the soul were like such a blank tablet then truths would be in us as the shape of Hercules is in a piece of marble when the marble is entirely neutral as to whether it assumes this shape or some other." Instead, our mind must be like veined marble:

if there were veins in the block which marked out the shape of Hercules rather than other shapes, then that block would be more determined to that shape and Hercules would be innate in it, in a way, even though labor would be required to expose the veins and to polish them into clarity. (NE Preface, 52)

These remarks bring out a fundamental difference between the Leibnizian and Lockean conceptions of human mind. If Locke has granted us native capacities for making cogent inferences, for Leibniz such capacities are "pure powers" which are "mere fictions, unknown to nature and obtainable only by abstraction." The Leibnizian mind, by contrast, is "not a bare faculty, consisting in a mere possibility of understanding" certain truths (including correct inferences), but "a disposition, an aptitude, a preformation, which determines our soul and brings it about that they are derivable from it." ${ }^{68}$ Syllogism, in the strict sense specified above, partly constitutes this native preformation. ${ }^{69}$ Locke could retort, of course, that this

${ }^{66} \mathrm{NE}$ I.i.4, 76. Here Leibniz invokes the scholastic distinction between logica naturalis and logica artificialis (see Zabarella's De Natura Logicae, I.xii). The two have the same content but different modes of representation: the "only difference" made through artificial logic "is that [the logical laws] being put in writing and made easier to take in all at once enables one to see them more clearly with a view to developing and applying them" (NE IV.xvii.4, 480). Christian Wolff will further develop this distinction and argue that a correct artificial logic — the Aristotelian syllogistic - is none other than a distinct representation of natural logic, which comprises the "rules prescribed by God to the understanding, and the natural aptitude to act accordingly" (German Logic, XVI.iii).

${ }^{67}$ Essay, I.i.5; I.i.9. Leibniz needs the notion of implicit knowledge to flesh out his view that we always possess (innate) knowledge of the necessary laws of reasoning. On Locke's polemic against this kind of view, see Samuel Rickless, "Locke's Polemic."

${ }^{68} \mathrm{NE}$ II.i.2, I IO; I.i.I I, 80 .

${ }^{69}$ Leibniz does not make this point explicit. For Wolff and most Wolffian logicians, though, it is clear that the natural logic in use (utens), which is the foundation of a correct artificial theory (docens) of logic, must be innate. See Wolff, Latin Logic, Prolegomena, §6; Johann Reusch, Systema logicum, §ऽ І05-Iо; Alexander Baumgarten, Acroasis logica, §§Io-I I; and Johann Formey, Elementa philosophiae, Prolegomena, I 4 . 
claim about the richly textured innate constitution of our mind is just another metaphysical speculation without any empirical basis.

Once the disagreement over syllogism comes down to this level, we have the starting point for evaluating it in a philosophically fruitful way. There may be multiple perspectives from which to do so. From the Kantian standpoint, for instance, both Leibniz and Locke have failed to establish claims about the authority of syllogism by appealing to a theory of mind. For each of them has only given us a kind of physiology of human intellect, which pertains to the "question of fact" (quaestio facti) as regards, say, what capacities or knowledge we naturally possess. This does not answer the "question of right" (quaestio juris) or of normativity, as both philosophers have intended to do. ${ }^{70}$ We may frame a similar charge in Fregean terms: Both Locke and Leibniz have committed some form of logical psychologism, by grounding logical laws on laws of how the mind works as a matter of empirical or metaphysical fact. In so doing, both of them have somehow conflated what causes and what justifies a logically correct formation of thought and failed to recognize that, just because logical laws prescribe how we ought to think, it does not follow that the source of their normativity must have ultimately to do with the human mind that thinks. Moreover, facts about the human mind-be they empirical or metaphysical ones-are always contingent in some sense, and so cannot ground the absolute necessity of logical laws. ${ }^{71}$

It will take another paper to flesh out these charges and to investigate whether Locke's and Leibniz's accounts are really susceptible to them. My present purpose is only to show that, by focusing on some of the foundational issues raised in Locke's critique of syllogism, we have brought him into what he would recognize as a genuine "conversation" about logic that cannot end with a simple declaration of winners and losers. Leibniz's New Essays has in a way enacted part of this conversation, during which Philalethes (Locke) says:

I am beginning to form an entirely different idea of logic from my former one. I

took it to be a game for the schoolboys, but I now see that, in your conception of it,

it involves a sort of universal mathematics. (NE IV.xvii.8, 486-87)

This is a carefully worded statement. Locke is not made to concede that logic is indeed universal mathematics, but only to recognize that he now faces a notion of logic that begs to differ from the scholastic one. Some of his previous arguments, if they were effective with respect to the latter notion, may have little force against the former. Whether this will turn out be the case, Leibniz does not tell us in the New Essays. Nonetheless, the recognition expressed in the quoted passage has gestured toward an upgraded and potentially richer exchange about formal logic that readers may continue in their own reasoned manner.

${ }^{70} \mathrm{See}$, for instance, Mrongovius, 29:764, 78 I-82. Kant's analysis is explicitly about Locke's and Leibniz's account of intellectual concepts, such as "cause." I have shown elsewhere that the same analysis, insofar as it concerns normativity, applies to logical rules (Lu-Adler, "Epigenesis").

${ }^{71}$ Frege, Grundgesetze, xiv-xxvi; "Logic"; and "Thought," 58-59. 


\subsection{Logical Norms and Rational Agency}

In section 2 and section 3.I, I drew attention to Locke's views on how each individual, as a free agent, ought to relate to logic in her intellectual activities. Those views were premised on the notion of logic as an artificial tool, extrinsic to the native capacities of our mind, which we can choose whether to adopt. Leibniz submitted a different notion of logic, according to which logic represents the laws that we de facto follow whenever we think in logically correct ways, regardless of whether we are aware of them or know what they are. Insofar as this Leibnizian notion is closer to how we tend to see logic today, it is tempting for us to brush aside the way in which Locke conceived logic and its relation to agency.

The Lockean conception cannot be easily dismissed, however. To see this, we may distinguish two ways for formal-logical rules to serve as norms. Leibniz offered a way to defend them as evaluative norms by which we can measure, say, whether a given inference is valid, inference being more like an objective existence than an act taking place in a thinker's mind. Locke's primary concern, however, was whether to adopt formal-logical rules as directive norms by which rational agents ought to carry out their inferential activities among other things..$^{72}$ This concern remains even if we grant that logical rules can be used to assess the logical qualities of thoughts or explain what makes inferences logically cogent.

More specifically, a Lockean would stress that logically cogent inferences do not just happen to us and that logical rules cannot regulate our thinking activities in the same way as laws of physics regulate our bodily movements. To illustrate, suppose I have correctly inferred one thing from another without tracing out all the intermediate steps syllogistically. Someone else may reconstruct the inference in accordance with certain syllogistic rules and thereby demonstrate its cogency. It does not mean that my inferential activity is in effect directed by those rules. I myself would have to be able to identify the appropriate syllogistic rules for constructing my inference and see how the conclusion follows from the premises. Thinking logically, as Christine Korsgaard puts it, is "an act of self-determination." As for when making inferences syllogistically counts as self-determination, Locke has set the bar quite high. On his account, it is not enough that one consciously and correctly applies syllogistic rules in one's inferential activities. One must also know whence those rules derive their force, or why some syllogistic forms, but not others, are valid. In other words, if an individual decides to subject her inferential activities to syllogistic rules, she must do so for the right reason — not because she has been instructed to follow those rules but solely thanks to her reasoned conviction about their force. ${ }^{74}$

Meanwhile, even if one is convinced about the authority of certain logical laws as evaluative norms, it still does not follow that they can be rightfully prescribed as

\footnotetext{
${ }^{72}$ This distinction between evaluative and directive norms is adapted from Steinberger, "Three Ways."

${ }^{73}$ Korsgaard, Self-Constitution, 69.

${ }^{74}$ I follow LoLordo in holding that this capacity to determine oneself to act through reason, or "rational self-determination," constitutes "the core of full-fledged free agency" for Locke (LoLordo, Moral Man, 53, defended in 53-62). On scholarly disagreements about how to interpret Locke's notion of free agency, see Rickless, "Locke on Freedom."
} 
directive norms, which pertain to our actual thinking activities. We may connect this point to a post-Fregean controversy over the relation between logic and reasoning. According to Frege, logical laws are "norms of thought" in that they "prescribe universally how one should think if one is to think at all."75 Such norms are supposed to be absolutely binding, without regard to contingent situations of thinking. For logical laws are laws of truth, where truth or the property of being true is independent of whether what is true is held as such by any thinking subject. ${ }^{76}$ On this view, as Gilbert Harman renders (and then challenges) it, logic is a science of truth that also plays a "special role" in reasoning. ${ }^{77}$ Harman's skepticism about there being any special relation between logic (in the Fregean sense) and reasoning has set in motion an ongoing debate over logical normativity. ${ }^{7}$ The title of one of his articles pithily captures one side of this debate: "a logic is not a theory of reasoning and a theory of reasoning is not a logic."79

Locke's critique of syllogism similarly serves to drive a wedge between logic (construed as a theory of truth) and reasoning (as a mental process that involves empirically situated agents). Granted (with Leibniz): no amount of observations about our actual reasoning activities can disprove the syllogistic logic, insofar as it claims to be strictly concerned with truth, cogency etc. as objective properties, independently of whether they are so perceived by individual subjects. Still, the phenomenon that most of us make correct inferences without ever being acquainted with syllogism suggests that the burden of proof lies with whoever wishes also to prescribe syllogistic rules as directive norms for how we ought to regulate, say, our inferential activities in order to count as rational. That is, even if the syllogistic logic provides an adequate theoretical basis for evaluating given inferences as regards their logical qualities, it does not thereby qualify as a correct theory of reasoning-either of how we actually, or of how we ought, to carry it out.

In that connection, Locke's theory of reasoning does not so much replace the Aristotelian syllogistic with another logic, as it describes a model of inference, as people commonly experience it, that involves no conscious appeal to syllogistic rules ${ }^{80}$ The point of this description is not to show what objectively explains the logical cogency of an inference, but to uncover what process an ordinary person can be reasonably expected to follow in order to perceive connections among her thoughts with her own mind's eyes. Certainly, Locke's theory does not falsify the Leibnizian proposition that we causally depend on, and in that sense implicitly use, syllogistic rules whenever we make valid inferences. Nonetheless, it at least suggests that we may have more than one way to see connections among our thoughts and

${ }^{75}$ Frege, Grundgesetze, xv.

${ }^{76}$ Frege, "Logic," I 39; and "Thought," 58.

${ }_{77}^{77}$ arman, "Logic and Reasoning," I Iо.

${ }^{78}$ Harman's initial arguments are in "Logic and Reasoning" and Change in View. For critical reviews of the ongoing debates over logical normativity inspired by Harman's work, see Steinberger, "Three Ways"; and Patrick Allo, "Logic."

${ }^{79}$ Harman, "Internal Critique."

${ }^{80} \mathrm{An}$ ordinary reasoner, on the notion of free agency I have attributed to Locke, must nevertheless subject her reasoning activities to some kind of rules. The question, which I have no room to pursue in this paper, is what these rules can be and what it means to make a conscious appeal to them. In particular, does this require that the subject be clearly and introspectively aware of them while conducting a piece of reasoning, or merely that she be able to show how her reasoning accords with the relevant rules? 
that our understandings may be "no less different than our Palates," varying from individual to individual. ${ }^{81}$ As long as this possibility remains open, no logical rules can serve as the universal directive norms for our thinking activities and no single model of reasoning as the universal standard of rationality.

\section{方. C O N C L U S I O N}

I have explored two aspects of Locke's relation to logic. One has to do with the ground on which to authenticate a putative logical theory as correct. The other pertains to the relation between logic and actual reasoning that involves agency. In these terms, I reassessed Locke's critique of syllogism. His main point, I argued, was not that there was anything intrinsically wrong with syllogism (or any kind of formal logic), but that we should recognize and use it only as what it is: namely, one among many artificial and limited tools. In view of his interest in promoting free exercises of our rational agency, he was especially intent on warning us against unreasoned, prejudicial attitudes towards such tools.

There are several ways to take this reading further. I already indicated the likelihood that it can be connected with the more recent debate on logical normativity (section 3.3). Although the logic under scrutiny differs from one case to the other (Aristotelian syllogistic versus Fregean logic), the basic philosophical question about the relation between logic and agent-centric reasoning posed by Locke's critique of syllogism is a generalizable one. After Harman's emphatic fashion, we may recast the question as follows: What does logic (as a theory of truth) have to do with rationality? Whoever wishes to think deeper about Locke's challenge in this regard—with the Leibnizian logic as his new target—may benefit greatly from examining the latest debates over logical normativity. The direction of exegetical inspiration, of course, can also be the other way around.

Meanwhile, my interpretation of Locke's relation to logic has also provided a starting point for reconsidering his influence on the developments in eighteenthcentury German logic, especially in the hands of Wolff, Kant, and various Wolffians in between. ${ }^{82}$ Two most noteworthy trends in those developments are traceable to the aspects of Locke's take on formal logic highlighted in this paper.

On the one hand, in typical Wolffian logic texts, one can sense an acute awareness of the need to establish the Aristotelian syllogistic as the correct logic. In addressing this need, Wolff evidently recognizes the importance of taking into account how we ordinarily experience the use of our intellectual faculties. Of the three tests he invokes to verify that he has discovered the true logic, the second one is the "natural way of thinking" as the commoners experience it, and which by Wolff's observation is "the very same with" what he has articulated in his theoretical logic (with syllogism at its core).$^{83}$ Even more tellingly, Wolff argues that logic must

${ }^{8}$ Essay, Epistle, 8 .

${ }^{82}$ For a general assessment of Locke's influence on the German Enlightenment [Aufklärung], see Klaus Fischer, "German Enlightenment." It is worth adding that the doctrine of prejudice is central to the Enlightenment thinking. For a comprehensive study of theories of prejudice from Bacon and Locke to Kant in that connection, see Werner Schneiders, Aufklärung und Vorurteilskritik.

${ }^{8}$ Wolff, German Logic, lxxxi-lxxxiii. The tests in question constitute the bulk of the practical part (logica practica) of the Wolffian logic, which follows the theoretical part (logica theoretica) and is included largely to confirm the truth of the latter. 
borrow its grounding principles (principia) from empirical psychology as well as from ontology ${ }^{84}$ Logic as a theory, however, does not thereby fold itself into either ontology or psychology. What connects psychology and logic is the question of grounding: the justificatory basis of a correct logic lies (at least partly) in psychology, but logic is not therefore the same as psychology. They are still distinct sciences.

On the other hand, for some of the philosophers who were Wolffian to some extent but were at the same time greatly influenced by Locke's works, studies of the subjective conditions of thought occupy a remarkably different place in a logical theory. One such philosopher was Martin Knutzen, with whom Kant studied logic and metaphysics at Königsberg. ${ }^{85}$ In Knutzen's Elementa philosophiae rationalis seu logicae (I 747), logic has two principal parts. One is universal logic (logica universalis), which presents the laws regulating our cognitive operations in general. The other is special logic (logica specialis), which explicates how we may deviate from those laws and commit errors and, accordingly, prescribes remedies for avoiding errors and cognizing truth in practice. The Lockean influence is particularly evident in the latter part. ${ }^{86}$

Kant developed his theory of logic through critical adaptations of these trends. His well-known distinction between pure and applied logics is modeled on Knutzen's between universal and special logics, while it also signals a further departure from the Wolffian tradition than the latter did. In a way, this distinction epitomizes Kant's responses to both Locke's and Wolff's views regarding the foundation of logic. Earlier, I quoted Kant as claiming that Locke's Essay is the ground of true logic. Kant never backs away from this claim insofar as it involves the acknowledgement that logic must build on some analysis of human understanding. It is just that, alongside the distinction between pure and applied logics, there is now also a distinction between pure (a priori) and empirical studies of human understanding. If logic must draw its grounding principles from these studies, Kant insists on being crystal clear about which study grounds which branch of logic. As he puts it in the Critique of Pure Reason, pure logic "has no empirical principles, thus it draws nothing from psychology (as one has occasionally been

${ }^{84}$ Wolff, Preliminary Discourse, 89-9 I, I I 7, I 35, I 39, I 44, I 54, I 56 (references are to paragraph numbers). For iterations of the same point, see Reusch, Systema logicum $(\$ 78)$ and Formey, Elementa philosophiae (Prolegomena, I2), both of which are representative Wolffian texts.

${ }^{85}$ Knutzen was closely acquainted with Locke's Conduct. He drew up the plan to translate this work (as Anleitung des menschlichen Verstandes), a plan to be carried out by Georg David Kypke, an early friend and colleague of Kant's. On this fact, see Locke, Lockens Anleitung, Preface; and Manfred Kuehn, Kant, I IO-I I. For a contrast of Knutzen's logic with Wolff's in light of Locke's influence on the former, see Benno Erdmann, Knutzen, I07-I3. On the extent of Knutzen's influence on Kant, see Erdmann, Knutzen, I30-48; and Kuehn, Kant, 76-86, 88-89, 93-94.

${ }^{86}$ Knutzen, Elementa logicae, 45-46, 3 I3-I 5. Knutzen's universal logic treats the same subject as Wolff's theoretical logic did. His special logic, however, differs from Wolff's practical logic not only in content but also in its relation to the previous part. It contains a detailed treatment of the symptoms, causes, and remedies of error. In particular, Knutzen explains how error relates to prejudice and gives a detailed account of the latter (Knutzen, Elementa logicae, 322-82), which resembles Locke's theory of prejudice in the Conduct. Notably, Knutzen's special logic is not a standalone piece of logic but a part of logic that is meaningful only in relation to the universal logic, which must be set down first. It "supplements" the universal logic much like how Locke's theory of prejudice might supplement the traditional logic — not by offering an alternative logic but by specifying the subjective conditions under which individual agents may relate to the latter. 
persuaded), ... and everything in it must be completely a priori." Applied logic, by contrast, is "directed to the rules of the use of the understanding under the subjective empirical conditions that psychology teaches us" and therefore "has empirical principles." ${ }^{77}$ Along the same lines, Kant rejects the Leibnizian-Wolffian position that artificial logic and natural logic represent the same rules in different manners. In his view, these are essentially different kinds of logic with distinct subject matters and separate grounds. Artificial logic inquires about the objective laws of thought and does so completely a priori, independently of experience. Natural logic, by contrast, presents the subjective rules of thought, namely rules by which we commonly use our intellectual faculties under all sorts of subjective conditions (including various prejudices that incline us to error). ${ }^{88}$

A great deal needs to be added to substantiate this narrative regarding how Locke's critique of the Aristotelian logic might have inspired some of the most significant developments in the eighteenth-century philosophical discourse on logic. The point of outlining this narrative here is nevertheless clear. That is, we would not be able to appreciate Locke's unique role in prompting those developments unless we begin by separating logic (as a theoretical discipline) and philosophical questions about its justificatory grounds and its bearing on our ordinary experience of intellectual activities ${ }^{89}$ Such issues, as Locke presented them, are extremely difficult to address. Although my narrative above ended with Kant, neither he nor any working philosopher today has decisive answers-as we can tell from the renewed interest in, and ongoing debates over, the relation between logic and thought. ${ }^{\circ}$

\section{B I B L I O G R A P H Y A N D A B B RE V I A T I O N S}

Allo, Patrick. "Logic, Reasoning and Revision." Theoria 82 (20I6): 3-3 I. ["Logic"]

Aquinas, Thomas. Commentary on Aristotle's Posterior Analytics. Translated by Richard Berquist. Notre Dame: Dumb Ox Books, 2008. [Commentary]

Ashworth, E. Jennifer. “'Do Words Signify Ideas or Things?' The Scholastic Sources of Locke's Theory of Language." Journal of the History of Philosophy I9 (I98 I) : 299-326. ["Words"]

Bacon, Francis. The Instauratio magna Part II. Edited by Graham Rees and Maria Wakely. Oxford: Oxford University Press, 2004. [Instauratio]

Barnes, Jonathan. "Locke and the Syllogism." In Whose Aristotle? Whose Aristotelianism?, edited by R. W. Sharples, I05-32. Aldershot: Ashgate, 200I. ["Syllogism"]

${ }^{8}$ CPR A $53-54 / \mathrm{B} 77-78$.

${ }^{88}$ BL 24:I 7-I 8.

${ }^{89}$ By making this distinction and focusing on philosophy of logic, I am not suggesting that Locke made no historically important contributions to "logic" proper, in whatever senses of the term recognized by his contemporaries and immediate followers. In this respect, an interested reader has much to learn from the New Logic interpretation, which has a significantly different goal than mine. It represents an attempt to construct a coherent historical narrative that brings together all the major seventeenth-and eighteenth-century developments involving logic. This historical project no doubt has its own value. But again, even this project can begin from multiple angles, including that of philosophy of logic.

${ }^{9} \mathrm{I}$ presented the earliest version of this paper, "God, Purposive Fit, and the Authority of Logical Rules-Locke's Criticism of Syllogism Reconsidered," at the seventeenth South Central Seminar in Early Modern Philosophy (UT-Austin, October 20 I 5). I am grateful to the participants at that conference for their feedback. I also want to extend special thanks to Kenneth Winkler for his extremely generous and thoughtful comments on a recent version of the paper. Any infelicities that may remain are mine alone. 
Baumgarten, Alexander Gottlieb. Acroasis logica in Christianum L. B. de Wolff. Halle: Hemmerde, I76I. [Acroasis logica]

Beaney, Michael, ed. The Frege Reader. Oxford: Blackwell, I997. [Reader]

Blackburn, Simon. Oxford Dictionary of Philosophy, 3rd ed. Oxford: Oxford University Press, 2016. [Dictionary]

Buickerood, James G. "Locke and the Rise of Facultative Logic." History and Philosophy of Logic 6 (I985): I 57-90. ["Facultative Logic"]

Dawson, Hannah. Locke, Language and Early-Modern Philosophy. Cambridge: Cambridge University Press, 2007. [Locke]

De Rijk, L. M. "Semantics and Ontology: An Assessment of Medieval Terminism." In Medieval Supposition Theory Revisited, edited by E. P. Bos, I3-59. Leiden: Brill, 2013.

Diogenes Laertius. Lives of Eminent Philosophers, 2 vols. Translated by Robert Drew Hicks. Loeb Classical Library, London: Heinemann, I925. [Lives]

Erdmann, Benno. Martin Knutzen und seine Zeit. Leipzig: Voss, I 876. [Knutzen]

Fischer, Klaus P. "John Locke in the German Enlightenment." Journal of the History of Ideas 36 (I975): 43 I-46. ["German Enlightenment"]

Formey, Johann Heinrich Samuel. Elementa philosophiae. Berlin: Haude and Spener, 1746.

Fowler, Thomas. "Introduction" and "Notes." In Locke, Locke's Conduct, ix-xxiv, 105-36.

Franklin, James. "Artifice and the Natural World." In Haakonseen, Cambridge History, 8 I7-53. ["Artifice"]

Frege, Gottlob. Grundgesetze der Arithmetik, vol.I. In Beaney, Reader, I94-223. [Grundgesetze]

. "Logic." In Beaney, Reader, 227-50.

—. "Thought." In Beaney, Reader, 325-45.

Gaukroger, Stephen. Cartesian Logic. Oxford: Oxford University Press, I989.

Groarke, Leo. "Informal Logic." The Stanford Encyclopedia of Philosophy, edited by Edward N. Zalta, URL = http://plato.stanford.edu/archives/sum20 $5 /$ entries/logic-informal/, 2015.

Haack, Susan. Philosophy of Logics. Cambridge: Cambridge University Press, I 978.

Haakonseen, Knud, ed. The Cambridge History of Eighteenth-Century Philosophy, 2 vols. Cambridge: Cambridge University Press, 2006. [Cambridge History]

Harman, Gilbert. Change in View. Cambridge: MIT Press, I986.

. "Internal Critique: A Logic is Not a Theory of Reasoning and A Theory of Reasoning is Not a Logic." In Studies in Logic and Practical Reasoning, vol. I: Handbook of the Logic of Argument and Inference: The Turn towards the Practical, I7 I-86. Amsterdam: Elsevier, 2002.

. "Logic and Reasoning." Synthese 60 (1984): 107-27.

Kant, Immanuel. The Blomberg Logic. In Kant, Lectures on Logic, I-246. [BL]

. Critique of Pure Reason. Translated and edited by Paul Guyer and Allen Wood. Cambridge: Cambridge University Press, I998. [CPR]

. The Jäsche Logic. In Kant, Lectures on Logic, 517-640. [JL]

Kants Gesammelte Schriften, 29 vols. Berlin: Walter de Gruyter, I902-83. [AA]

. Lectures on Logic. Translated and edited by J. Michael Young. Cambridge: Cambridge University Press, I992.

. Metaphysics Mrongovius. In Kant, Lectures on Metaphysics, translated and edited by Karl Ameriks and Steven Naragon, I07-286. Cambridge: Cambridge University Press, I997. [Mrongovius]

Kenney, W. Henry. John Locke and the Oxford Training in Logic and Metaphysics. PhD Diss., Saint Louis University, I959. Available from ProQuest Dissertations \& Theses Global. (301873589) [Oxford Training]

Knutzen, Martin. Elementa philosophiae rationalis seu logicae. Königsberg and Leipzig: Hartung, I747. [Elementa logicae]

Korsgaard, Christine. Self-Constitution: Agency, Identity, and Integrity. Oxford: Oxford University Press, 2009.

Kuehn, Manfred. Kant: A Biography. Cambridge: Cambridge University Press, 200I.

Leibniz, G. W. New Essays on Human Understanding. Edited by Peter Remnant and Jonathan Bennett, Cambridge: Cambridge University Press, I996. [NE]

Locke, John. Of the Conduct of the Understanding by John Locke. Edited by Paul Schuurman. PhD Diss., University of Keele, 2000. http://hdl.handle.net/I765/I I 839 [Conduct]

—. The Correspondence of John Locke in Eight Volumes. Edited by E. S. de Beer. Oxford: Clarendon, I976-89. [Correspondence]

- An Essay Concerning Human Understanding. Edited by Peter H. Nidditch. Oxford: Oxford University Press, I975. [Essay] 
. Johann Lockens Anleitung des menschlichen Verstandes. Translated by Georg David Kypke. Königsberg: Hartung, I75 5. [Lockens Anleitung]

. The Life of John Locke, vol.2. Edited by Lord King. London: Colburn and Bentley, I 830. [Life]

. Locke's Conduct of the Understanding. Edited by Thomas Fowler. Oxford: Clarendon, I90I. [Locke's Conduct]

- The Works of John Locke in Nine Volumes, I 2 th edition. London: Rivington, I 824. [Works]

LoLordo, Antonia. Locke's Moral Man. Oxford: Oxford University Press, 20I 2. [Moral Man]

Lowe, E. J. The Routledge Guidebook to Locke's Essay Concerning Human Understanding. London: Routledge, 20I3. [Routledge Guidebook]

Lu-Adler, Huaping. "Epigenesis of Pure Reason and the Source of Pure Cognitions: How Kant is No Nativist about Logical Cognition.” In Rethinking Kant, vol. 5, edited by Pablo Muchnik and Oliver Thorndike. Newcastle: Cambridge Scholarly Publishing, forthcoming. ["Epigenesis"]

Michael, Frederick S. "Why Logic Became Epistemology: Gassendi, Port Royal and the Reformation in Logic." In Logic and the Workings of the Mind, edited by Patricia Easton, I-20. Atascadero: Ridgeview, I997. ["Epistemology"]

Molyneux, William. Dioptrica Nova. London: Tooke, I 692.

Ott, Walter. Locke's Philosophy of Language. Cambridge: Cambridge University Press, 2004. [Language]

Parkinson, George $\quad$ H. R. "Review of Risse, Die Logik der Neuzeit, Bd. 2." Studia Leibnitiana, 3 ( I97 I): 300-303. ["Review of Risse"]

Reusch, Johann Peter. Systema logicum antiquiorum atque recentiorum item propria praecepta exhibens, 3 rd edition. Jena: Cröcker, I750. [Systema logicum]

Rickless, Samuel. "Locke's Polemic Against Nativism.” In Locke’s Essay Concerning Human Understanding, edited by Lex Newman, 33-66. Cambridge: Cambridge University Press, 2007. ["Locke's Polemic"]

. "Locke on Freedom." The Stanford Encyclopedia of Philosophy, edited by Edward N. Zalta, URL = http://plato.stanford.edu/archives/win20 5 /entries/locke-freedom/, 20 I 5.

Risse, Wilhelm. Die Logik der Neuzeit II: I640-I 780. Stuttgart-Bad Cannstatt: Frommann-Holzboog, I970.

Schneiders, Werner. Aufklärung und Vorurteilskritik. Stuttgart-Bad Cannstatt: Frommann-Holzboog, I983.

Schuurman, Paul. "General Introduction.” In Locke, Conduct, I 5-I 48.

. Ideas, Mental Faculties, and Method. Leiden: Brill, 2004. [Ideas]

Sgarbi, Marco. The Aristotelian Tradition and the Rise of British Empiricism. Dordrecht: Springer, 20 I3. [British Empiricism] Kant and Aristotle. Albany: SUNY Press, 2016.

Schouls, Peter A. Reasoned Freedom, Ithaca: Cornell University Press, I992.

Steinberger, Florian. "Three Ways Logic May Be Normative" (unpublished manuscript, April I 3, 20 I 7), Portable Document Format. https:/ / www.academia.edu/29587582/Three_ways_in_which_logic_ might_be_normative_Draft. ["Three Ways"]

Walmsley, Peter. Locke's Essay and the Rhetoric of Science. Lewisburg: Bucknell University Press, 2003. [Rhetoric]

Winkler, Kenneth. "Lockean Logic.” In The Philosophy of John Locke, edited by Peter R. Anstey, I 54-78. London: Routledge, 2003.

Wolff, Christian. Logic, or Rational Thoughts on the Powers of the Human Understanding. London: Hawes et al., I770. [German Logic]

. Philosophia rationalis sive logica, 3 rd edition. Frankfurt and Leipzig: Renger, I740. [Latin Logic]

Preliminary Discourse on Philosophy in General. Translated by Richard J. Blackwell. Indianapolis: Bobbs-Merrill, I963. [Preliminary Discourse]

Wynne, John. An Abridgment of Mr. Locke's Essay concerning Humane Understanding. London: Churchill and Castle, I696. [Abridgment]

Yolton, John W. "Locke and the Seventeenth-Century Logic of Ideas." Journal of the History of Ideas I 6 (I955): 43 I-52. ["Logic of Ideas"]

Zabarella, Jacopo. De Natura Logicae. In Zabarella, Opera Logica, Hildesheim: Olms, I966. 
